Kunuz: Journal of Islamic Banking and Finance Vol. 1, No. 1 (2021): 1-9 Website: http://ejournal.iain-manado.ac.id/index.php/kunuz

\title{
IMPLEMENTASI AKAD MURABAHAH PADA PEMBIAYAAN PENSIUN DI BANK SYARIAH MANDIRI KANTOR CABANG PEMBANTU MANADO KAIRAGI
}

\section{Fahri Suratinoyo}

Fakultas Ekonomi dan Bisnis Islam, Institut Agama Islam Negeri Manado

E-mail: fahri.suratinoyo@iain-manado.ac.id

\section{Rosdalina Bukido}

Fakultas Syariah, Institut Agama Islam Negeri Manado

E-mail: rosdalina.bukido@iain-manado.ac.id

\section{Andi Mukarramah Nagauleng}

Fakultas Tarbiyah dan Ilmu Keguruan, Institut Agama Islam Negeri Manado, E-mail: andi.mukarramah@iain-manado.ac.id

\begin{abstract}
ABSTRAK
Penelitian ini bertujuan untuk mengetahui implementasi akad murabahah pada pembiayaan pensiun di Bank Syariah Mandiri KCP Manado Kairagi sudah sesuai dengan fatwa MUI atau belum. Penelitian ini menggunakan metode penelitian kualitatif, yang mana peneliti akan menguraikan atau menggambarkan mengenai implementasi akad murabahah pada pembiayaan pensiun di bank Syariah mandiri KCP Manado Kairagi. Berdasarkan hasil penelitian, implementasi akad murabahah pada pembiayaan pensiun di bank Syariah mandiri KCP Manado Kairagi telah mengatur syarat dan ketentuan yang dibutuhkan ketika akan mengajukan pembiayaan pensiun pada PT Bank Syariah mandiri KCP Manado Kairagi. Dalam pembiayaan pensiun ini harus terbebas dari riba, gharar, maisyir dan juga harus halal.
\end{abstract}

Kata kunci: Akad murabahah; bank Syariah; pembiayaan pensiun. 


\section{PENDAHULUAN}

Masalah ekonomi merupakan masalah yang kerap terjadi dalam bermacam kehidupan manusia (Kina, 2017). Hal tersebut diakibatkan oleh semakin meningkatnya tuntutan kebutuhan dan keinginan masyarakat, dan kebutuhan serta keinginan tersebut tidak sesuai dengan kemampuan mereka, lembaga keuangan saat ini hadir dan berperan penting dalam memenuhi kebutuhan masyarakat. Lembaga yang dimaksud adalah bank, mengingat pentingnya tuntutan tersebut, maka bank merupakan salah satu lembaga keuangan yang menyelesaikan permasalahan perekonomian melalui berbagai produk serta jasa untuk melayani kebutuhan masayarakat (Marlina \& Rahmat, 2018).

Perihal ini, bank tidak cuman berfungsi menyalurkan dana kepada masyarakat dalam wujud pembiayaan sebagai lembaga, tetapi juga berfungsi sebagai lembaga perantara antara anggota yang memiliki kelebihan dana dengan masyarakat yang memerlukan atau kekurangan dana (Mawaddah, 2015; Wiwoho, 2014). Menurut Undang-Undang Nomor 10 Tahun 1998 Tentang Perbankan, bank merupakan badan usaha yang menghimpun dana dari masyarakat yang berupa simpanan serta menyalurkan dana kepada masyarakat dalam bentuk kredit ataupun bentuk yang lain untuk meningkatkan taraf hidup masyarakat (Dahlan, 2012). Selanjutnya, dalam Undang-Undang Nomor 21 Tahun 2008 Tentang Perbankan Syariah Pasal 1 disebutkan bahwa perbankan Syariah adalah segala sesuatu yang menyangkut bank Syariah dan unit usaha Syariah, mencakup kelembagaan, kegiatan usaha, serta cara dan proses dalam melaksanakan usahanya (Arviyan, Arifin, Veithzal, \& Rivai, 2010).

Perbankan Syariah telah menjadi kenyataan umum di Indonesia termasuk di wilayah Propinsi Sulawesi Utara khususnya di Kota Manado, yang masyarakatnya minoritas muslim. Bisnis perbankan pada saat ini sangat penting bagi perkembangan perekonomian termasuk bisnis perbankan Syariah, dan bisnis Syariah pada saat ini berkembang sanggat pesat di Indonesia.

Bank yang berdasarkan prinsip Syariah sebagai suatu lembaga intermediasi yaitu menghimpun dana dari masyarakat dan menyalurkan kembali dana tersebut kepada masyarakat yang membutuhkan dalam bentuk fasilitas pembiayaan atau yang lainnya, pembiayaan merupakan salah satu kegiatan utama dan menjadi sumber utama pendapatan bagi bank Syariah (Arviyan et al., 2010). Jenis pembiayaan yang ada didalam bank Syariah yaitu pembiayaan modal kerja Syariah (Wiwoho, 2014), pembiayaan investasi Syariah (Permata, 2014), pembiayaan konsumtif (Pribadi, 2017), pembiayaan sindikasi, pembiayaan berdasarkan take over, pembiayaan letter of credit (Chadziq, 2017).

Bentuk pembiayaan perbankan Syariah berdasarkan prinsip Syariah harus dilandasi berbagai akad yang diperbolekan dalam Islam dan tidak boleh ada paksaan dalam melakukan akad kemudian harus terbesas dari yang namanya gharar, maisyir dan haram. Akad (ikatan, keputusan atau penguatan) atau 
perjanjian atau kesepakatan atau transaksi dapat diartikan sebagai komitmen yang terbingkai dengan nilai-nilai Syariah.

Akad dalam istilah fiqih adalah sesuatu yang menjadi tekad seseorang untuk melaksanakan, baik yang muncul dari suatu pihak maupun yang muncul dari dua pihak (Ascarya, 2018). Akad dalam makna luas inilah yang Allah inginkan dalam firman-nya:

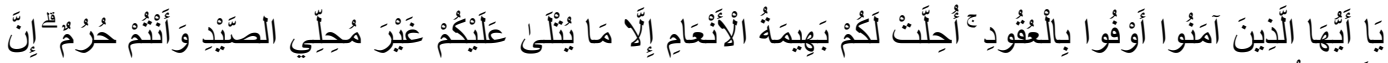

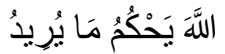

Terjemahnya:

"Hai orang-orang yang beriman, penuhilah aqad-aqad itu. Dihalalkan bagimu binatang ternak, kecuali yang akan dibacakan kepadamu (yang demikian itu) dengan tidak menghalalkan berburu ketika kamu sedang mengerjakan haji. Sesungguhnya Allah menetapkan hukum-hukum menurut yang dikehendaki-Nya" (Q.S Al-Maidah 5:1).

Ayat tersebut menjelaskan bahwa Allah memerintakan kepada hambaNya untuk memenuhi jani-janji yang telah diikrarkan baik janji prasetia hamba kepada Allah, maupun janji yang dibuat antara sesama manusia seperti yang bertalian dengan perkawinan, perdagangan dan sebagainya selama janji itu tidak melanggar syari'at Islam (Faizal, 2017; Ihwanudin \& Burhanudin, 2020).

Akad dalam pembiayaan perbankan Syariah antara lain Murabahah, mudharabah, musyarakah, kafalah, salam, istishna, ijarah, wakalah, hawalah, dan lain lain. Murabahah berasal dari Bahasa arab, rabahah, yurabihu, murabahatan yang berarti untung atau menguntunggkan (Eliza, 2019). Menurut Undang-Undang Nomor 21 Tahun 2008 tentang perbankan Syariah yang dimaksud dengan akad murabahah adalah akad pembiayaan suatu barang dengan menegaskan harga belinya kepada pembeli dan pembeli membayarnya dengan harga yang lebih sebagai keuntungan yang disepakati.

Senada dengan definisi ini, murabahah menurut Fatwa DSN-MUI No.04/DSN-MUI/IV/2000 tentang murabahah adalah menjual suatu barang dengan menegaskan harga belinya kepada pembeli dan pembeli membayarnya dengan harga yang lebih sebagai laba. Berdasarkan definisi di atas, dapat dipahami bahwa dalam murabahah harga beli dan harga jual plus keuntungan harus transparan dan diketahui oleh pihak yang melakukan transaksi.

Beberapa alasan yang menjadi sebab diminatinya akad ini adalah sebagai berikut (Rodliyah, 2016):

a. Murabahah adalah suatu mekanisme investasi pembiayaan jangka pendek dan dibandingkan dengan sistem profit and loss sharing (PLS), lebih mudah.

b. Mark-up dalam murabahah dapat ditentukan secara pasti yang merupakan jaminan bagi LKS dalam memberikan retrun kepada penyimpan dana dan 
juga dapat melakukan perbandingan dengan tingkat bunga yang ada di bank konvesional.

c. Murabahah menjauhkan ketidakpastian yang ada pada pendapatan dari bisnis-bisnis dengan sistem LPS.

d. Murabahah tidak memungkinkan LKS untuk mencampuri manajemen bisnis, karena LKS bukanlah mitra dari nasabah, sebab hubungan mereka dalam murabahah adalah hubungan antar penjual dan pembeli atau pemberi dan penerima pembiayaan.

Bentuk pembiayaan yang berdasarkan murabahah dapat dibagi lagi berdasarkan jenis penggunaannya (berdasarkan produk) yaitu untuk pembiayaan mutliguna, pembiayaan modal kerja, pembiayaan investasi, pembiayaan kendaraan bermotor, pembiayaan perumahan dan sebagainya. Konsep dan aplikasi pembiayaan dengan akad murabahah yang sederhana dan memudahkan penanganan administrasi bank Syariah merupakan faktor utama bank Syariah di Indonesia lebih banyak menerapkan prinsip murabahah dalam pembiayaan. Produk pembiayaan dengan akad murabahah yang mulai berkembang saat ini sangat beragam, salah satunya adalah pembiayaan pensiun (Prabowo, 2009).

Tujuan dari adanya program pensiun adalah untuk mengelola cadangan pendapatan karyawan selama masa jabatannya sebagai investasi dimasa yang akan datang. Untuk karyawan yang telah selesai masa kerja atau tidak dapat menghasilkan pendapatan, karyawan atau ahli warisnya akan menerima pembayaraan rutin selama masa hidupnya dan dengan demikian menerima pensiun. Pensiun dapat digunakan untuk kelangsungan hidup setelah tidak bekerja sebagai karyawan, dapat digunakan untuk modal komersial maupun kebutuhan lainnya. Tentu saja diperlukan lembaga penghimpun dana dan penyalur dana untuk memenuhi kebutuhan mereka. Oleh karena itu, walaupun masyarakat tidak lagi dalam usia produktif, pembiayaan pensiun merupakan salah satu pembiayaan yang berpotensi untuk meningkatkan kemandirian perekonomian masyarakat (Pratama, 2018).

Produk pembiayaan pensiun di Bank Syariah Mandiri Manado KCP Kairagi merupakan produk pembiayaan multiguna dimana pembiayan tersebut bisa digunakan untuk apa saja sesuai perjanjian antara pihak bank dengan nasabah dan harus sesuai dengan prinsip Syariah. Untuk pembiayaan pensiun di bank Syariah Mandiri KCP Manado Kairagi banyak diminati masyarakat Manado khususnya kalangan pensiun karena margin rendah dan prosesnya sangat mudah untuk calon nasabah karena mengigat calon nasabah BSM Manado KCP Kairagi sudah lumayan berumur dan tidak banyak melakukan aktivitas. Oleh sebab itu penulis ingin meneliti apakah pembiayaan pensiun dengan menggunakan akad murabahah di Bank Syariah Mandiri Manado KCP Kairagi sudah sesuai dengan prinsip Syariah berdasarkan Fatwa DSN-MUI No.04/DSN-MUI/IV/2000 ataukah fatwa tersebut tidak dijalankan sebagaimana mestinya. 


\section{METODE PENELITIAN}

Penelitian ini merupakan penelitian kualitatif pada pelaksanaannya dilakukan pencarian gambaran dan data deskriptif di lingkungan Bank Syariah Mandiri KCP Manado Kairagi yang dijadikan objek penelitian. Data primer diperoleh melalui wawancara, observasi kepada pihak-pihak yang terkait dengan masalah yang diteliti. Adapun yang menjadi subjek penelitian ini adalah marketing 1 orang, 1 orang bagian pembiayaan, 1 costumer service bagian pembukaan rekening, dan 1 orang nasabah. Adapun data sekunder diambil dari melalui dokumen-dokumen yang terkait dengan pembahasan peneliti ini seperti buku-buku, data kepustakaan, artikel, jurnal, yang berhubungan dengan pembahasan dan dokumen yang diambil dari BSM tersebut yang menunjang penelitian ini.

Analisis data yang digunakan melalui data reduction (reduksi data), display (penyajian data) dan conclusion drawing/verification (verifikasi). Dalam penelitian ini, peneliti menggunakan dua jenis triangulasi yaitu triangulasi sumber dan triangulasi teknik (Moleong, 2016).

Triangulasi sumber yaitu dengan cara membandingkan data hasil wawancara antar narasumber terkait dan membandingkan data hasil dokumentasi antar hasil dokumentasi dan dokumen. Triangulasi ini digunakan oleh peneliti untuk mengecek data yang diperoleh dari marketing dan nasabah di Bank Syariah Mandiri KCP Manado Kairagi. Triangulasi teknik ini digunakan oleh peneliti setelah mendapatkan hasil wawancara dari narasumber yang kemudian dicek dengan hasil observasi dan dokumentasi. Dari kedua teknik tersebut tentunya akan menghasilkan sebuah kesimpulan terkait implementasi akad murabahah pada pembiayaan pensiun di Bank Syariah Mandiri KCP Manado Kairagi.

\section{HASIL DAN PEMBAHASAN}

Murabahah adalah jual beli barang pada harga asal dengan tambahan keuntungan yang disepakati. Dalam murabahah, penjual harus memberitahu harga produk yang dia beli dan menentukan suatu tingkat keuntungan sebagai tambahannya. Murabahah adalah salah satu kontrak jual beli yang sangat umum dalam praktik dagang Islam ini dikenal juga sebagai jual beli dengan penambahan biaya (Triyanta, 2016).

Menurut Karim, murabahah lebih dikenal sebagai murabahah saja murabahah berasal dari kata ribhu (keuntungan). Adalah transaksi jual beli dimana bank bertindak sebagai penjual, sementara nasabah sebagai pembeli. Harga jual adalah harga beli bank dari pemasok ditambah keuntungan (margin) (Karim, 2007).

Hal yang paling esensial dari kontrak ini jika dibandingkan dengan jenis kontrak lain adalah dibenarkannya mengambil keuntungan yang dilakukan dengan pernyataan yang jelas. Atas dasar inilah, maka sebagian ahli fiqih menyebut 
kontrak ini dengan jual beli komoditas (sale of a commodity). Ini adalah jual beli yang adil dan transparan yang dapat dengan mudah dilakukan baik pada pasar biasa maupun dalam perbankan (Triyanta, 2016).

Menurut peneliti akad murabahah itu adalah akad jual beli dengan harga asal atau harga sebenarnya kemudian tambahan keuntungan disepakati antara keduanya sehingga tidak merugikan salah satu pihak. Misalnya, pihak A membeli barang dengan harga Rp. 50.000,- dan menjual kepada pihak B dengan harga Rp. 55.000,- Disini pihak A memberi tahu harga sebenarnya serta tambahan dari penjualan ini, sesuai data yang penulis dapatkan di lapangan, akad murabahah di Bank Syariah Mandiri KCP Manado Kairagi.

Akad yang digunakan dalam produk pembiayaan pensiunan di Bank Syariah Mandiri KCP Manado Kairagi menggunakan akad murabahah. Menjadi pertanyaan adalah mengapa menggunakan akad murabahah dalam prodak pembiayaan pensiun sedangkan murabahah sendiri yakni akad jual beli, jadi disini murabahah itu menyangkut tujuan dari nasabah. Contoh nasabah pembiayaan pensiun tujuannya untuk membeli tanah, rumah, mobil atau motor jadi disini menggunakan akad jual beli dengan dana dari bank tapi bank tidak harus membeli langsung barang yang dipesan oleh nasabah jadi pihak bank memberikan hak kepada nasabah untuk membelinya, oleh karena itu murabahah dibarengi dengan akad wakalah atau perwakilan.

Produk pembiayaan pensiunan di Bank Syariah Mandiri KCP Manado Kairagi merupakan salah satu produk yang masuk pada pembiayaan consumer. Pembiayaan consumer ini salah satu segmen bisnis di Bank Syariah Mandiri KCP Manado Kairagi yang memiliki kontribusi yang sangat besar untuk mengembangkan pertumbuhan bisnis Bank Syariah Mandiri KCP Manado Kairagi, untuk pembiayaan consumer ini banyak produknya, sesuai dengan pembiayaan pada pensiunan. Produk pembiayaan pensiunan ini hanya ditujukan kepada para pensiunan satker kementrian, pegawai negeri sipil daerah/pemkot. Sedangkan TNI, POLRI tidak termasuk dalam pembiayaan pensiun di Bank Syariah Mandiri KCP Manado Kairagi dan dalam pembiayaan pensiunan untuk pegawai yang masih 2 tahun pensiun itu sudah bisa melakukan pembiayaan pensiun di Bsm Kairagi, itu untuk non Kerjasama sedangkan untuk yang Kerjasama 5 tahun sudah bisa melakukan pembiayaan prapensiun.

Produk pembiayaan pensiunan ini juga merupakan salah satu produk yang cukup diminati oleh masyarakat setempat khususnya di kalangan pensiunan daerah Manado. Banyak para pensiunan yang memilih di bank syariah mandiri KCP Manado Kairagi ini, karena dilihat dari segi margin di bank syariah mandiri KCP Manado Kairagi ini bisa dikatakan memiliki margin yang paling rendah jika dibandingkan dengan bank-bank lain yang ada di Manado.

Terkait syarat dan ketentuan pada pengajuan pembiayaan pensiunan di bank syariah mandiri KCP Manado kairgi, ada beberapa hal yang harus diperhatikan ketika akan mengajukan pensiunan ini. Berikut adalah beberapa 
syarat dan ketentuan yang harus dipenuhi oleh calon nasabah pada pembiayaan pensiunan diantaranya, adalah cakap hukum, satker kementerian, pegawai negeri sipil daerah/pemkot, pada saat jatuh tempo pembiayaan, usia nasabah maksimal 74 tahun dan bersedia memindahkan pembayaran pensiunan bulanannya pada BSM KCP Manado Kairagi. Dokumen yang diperlukan adalah; Foto kopi SK Pensiun; KTP; Karip (kartu identitas pensiun); Pembukaan rekening; Rekening gaji pensiun; NPWP dan Pas foto $3 \times$ x 4 dua lembar.

Akad murabahah merupakan akad jual beli yang terjadi jika ada dua pihak yaitu penjual dan pembeli (Haryoso, 2017). Pengaplikasian di dunia perbankan adalah bank bertindak sebagai penjualnnya dan nasabah bertindak sebagai pembelinya. Dalam praktiknya murabahah pada produk pembiayaan pensiun di bank syariah mandiri KCP Manado Kairagi, bank bukanlah sebagai penjual murni yang menyediakan barang kebutuhan nasabah sebelum melakukan akad murabahah kepada nasabah. Posisi bank adalah sebagai lembaga pembiayaan bukan sebagai penjual barang. Nasabah yang melakukan pembiayaan nanti akan bertemu langsung dengan salah satu pihak bank, yang biasanya menawarkan produk pembiayaan pensiun, tetapi tidak saja menawarkan akan tetapi pihak bank juga menanyakan secara jelas kalau pembiayaannya untuk apa karena didalamnya harus sesuai dengan prinsip syariah, misalkan butuh modal usaha, untuk renovasi rumah, atau untuk biaya sekolah. Setelah itu apabila pihak nasabah sudah menyampaikan kebutuhannya yang diperlukan kepada pihak bank, baru kemudian pihak bank akan melakukan survei dan verifikasi apakah permohonan pembiayaan itu disetujui atau ditolak. Setelah bank menyetujuinya kemudian dari nasabah dan pihak bank akan melakukan akad pembiayaan, pengikatan jaminan dan surat bukti serah terima jaminan asli, apabilah sudah selesai melakukan akad maka pihak bank akan mencairkan dana pembiayaan pensiun dengan mentransfer langsung pada rekening nasabah. Kemudian pihak bank akan memberikan kuasa kepada nasabah untuk menggunakan dan pembiayaan tersebut sebagaimana yang dilakukan pada saat akad atau perjanjian awal.

Murabahah adalah salah satu bentuk jual beli yang bersifat amanah, rukun dan syarat murabahah yakini rukun murabahah ada 5 yang pertama penjual yaitu pihak yang memiliki, kedua pembeli yaitu pihak yang akan membeli barang, ketiga objek/barang yaitu barang yang diperjualbelikan, ke empat harga, ke lima ijab qabul yaitu pernyataan serah terima. Rukun-rukun ini ini harus diterapkan dalam pelaksanaan perbankan Syariah (Inggriani, 2011).

Pengaplikasian akad murabahah pada produk pembiayaan pensiun yang ada di Bank Syariah Mandiri KCP Manado Kairagi memang benar menggunakan akad murabahah yang dalam pengaplikasiannya telah memenuhi rukun-rukun seperti adanya penjual dan pembeli, serta objek akad/sighat di dalamnya. Untuk pembayaran angsuran, nasabah mulai membayar angsuran setelah melakukan penandatanganan akad dan untuk besar angsuran yang akan dibayar oleh nasabah setiap bulannya telah ditentukan diawal akad dan tidak akan berubah setiap bulannya sampai berakhirnya pembayaran angsuran pembiayaan (Rohmi, 2015). 
Kunuz: Journal of Islamic Banking and Finance Vol. 1, No. 1 (2021): 1-9 Website: http://ejournal.iain-manado.ac.id/index.php/kunuz

Artinya besarnya angsuran telah bersifat tetap sesuai dengan akad yang disepakati diawal.

Menurut Fatwa Dewan Syariah Nasional No. 04/DSN-MUI/IV/2000 tentang pembiayaan murabahah, dijelaskan dalam praktik pembiayaan pensiun dengan akad murabahah akadnya harus terbebas dari riba, gharar, dan maisyir. Dalam paraktiknya di Bank Syariah Mandiri KCP Manado Kairagi antara pihak bank dengan nasabah sebelumnya telah melakukan akad di awal dan pada saat akad telah disebutkan margin yang telah ditetapkan oleh bank dan pada proses penandatanganan tidak ada paksaan, ancaman ataupun tekanan, keduanya telah sama-sama ridho atu rela dan tidak ada salah satu yang dirugikan.

\section{KESIMPULAN}

Implementasi akad murabahah pada pembiayaan pensiun PT Bank Syariah Mandiri KCP Manado Kairagi telah mengatur syarat dan ketentuan yang dibutuhkan ketika akan mengajukan pembiayaan pensiun pada PT Bank Syariah Mandiri KCP Manado Kairagi. Dalam pembiayaan pensiun ini harus terbebas dari riba, gharar, maisyir dan juga harus halal. Hal ini didasarkan pada Fatwa Dewan Syariah Nasional No. 04/DSN- MUI/IV/2000 tentang pembiayaan murabahah.

\section{DAFTAR PUSTAKA}

Arviyan, Arifin, Veithzal, \& Rivai. (2010). Islamic Banking Sebuah Teori Konsep Dan Aplikasi. Jakarta: PT Bumi Aksara.

Ascarya. (2018). Akad Dan Produk Bank Syariah. Jakarta: PT Raja Grafindo Persada.

Chadziq, A. L. (2017). Manajemen Pembiayaan Bank Syariah: Sebuah Perkenalan. JES (Jurnal Ekonomi Syariah), 2(2).

Dahlan, A. (2012). Bank Syariah Teoritik, Praktik Kritik. Yagyakarta: Teras.

Eliza, E. (2019). Pengaruh Tingkat Margin Terhadap Keputusan Pengambilan Pembiayaan Murabahah Pada BPRS Gajahtongga Kotopiliang Kota Sawahlunto. Jurnal Ekonomi Dan Bisnis Dharma Andalas, 21(2), 143-153.

Faizal, B. T. W. (2017). Konsep Hukum Perjanjian di Indoneisa. VOICE JUSTISIA: Jurnal Hukum Dan Keadilan, 1(2), 109-129.

Haryoso, L. (2017). Penerapan prinsip pembiayaan syariah (murabahah) pada BMT Bina Usaha di Kabupaten Semarang. Law and Justice, 2(1), 79-89.

Ihwanudin, N., \& Burhanudin, M. (2020). Relavansi Pemikiran Ekonomi Hamka (1908-1981) Dalam Tafsir Al-Azhar Dengan Ekonomi Islam Di Indonesia. Eco-Iqtishodi: Jurnal Ilmiah Ekonomi Dan Keuangan Syariah, 1(2), 97-115.

Inggriani, A. (2011). Pembiayaan Al Murabahah Pada Bank Syariah Mandiri (Studi Kasus Pembiayaan Kepemilikan Rumah). Universitas Indonesia.

Karim, A. (2007). Bank Islam Dan Analisis Fiqih Dan Keuangan. Jakarta: PT Raja Grafindo Persada.

Kina, A. (2017). Mekanisme Penanganan Pembiayaan Murabahah Bermasalah Studi Pada Bmt Syari'ah Pare. IAIN Tulungagung Research Collections, 
Kunuz: Journal of Islamic Banking and Finance Vol. 1, No. 1 (2021): 1-9 Website: http://ejournal.iain-manado.ac.id/index.php/kunuz

3(2), 393-416.

Marlina, L., \& Rahmat, B. Z. (2018). Peran Lembaga Keuangan Syariah Dalam Mengimplementasikan Keuangan Inklusif Bagi Pelaku UMKM Tasikmalaya. Jurnal Ecodemica, 2(1), 125-135.

Mawaddah, N. (2015). Faktor-faktor yang mempengaruhi profitabilitas bank syariah. Jurnal Etikonomi, 14(2).

Moleong, L. (2016). Metodologi Penelitian Kualitatif. Bandung: Remaja Rosdakarya.

MUI, D. S. N. (2000). Fatwa DSN-MUI. No.04/DSN-MUI/IV/2000 Tentang Murabahah.

Permata, R. I. D. (2014). Analisis Pengaruh Pembiayaan Mudharabah Dan Musyarakah Terhadap Tingkat Profitabilitas (Return On Equity) (Studi pada Bank Umum Syariah Yang Terdaftar di Bank Indonesia Periode 2009-2012). Jurnal Administrasi Bisnis, 12(1).

Prabowo, B. (2009). Konsep Akad Murabahah Pada Perbankan Syariah (Analisa Kritis Terhadap Aplikasi Konsep Akad Murabahah Di Indonesia Dan Malaysia). Jurnal Hukum IUS QUIA IUSTUM, 16(1).

Pratama, A. (2018). Nasabah Menggunakan and Pembiayaan Pensiunan.

Pribadi, R. M. (2017). Analisis Pembiayaan Konsumtif Riil Pada Bank Syariah Di Indonesia. Liquidity, 6(1), 32-37.

Rodliyah, N. (2016). Application of Islamic Economic Law of Murabahah Funding In Islamic Banking. International Conference on Law, Business and Governance (ICon-LBG), 1.

Rohmi, P. K. (2015). Implementasi Akad Musyarakah Mutanaqishah pada Pembiayaan Kepemilikan Rumah di Bank Muamalat Lumajang. Iqtishoduna: Jurnal Ekonomi Islam, 4(1), 17-37.

Triyanta, A. (2016). Hukum Perbankan Syariah Regulasi, Implementasi, Dan Formulasi Kepatuhannya Terhadap Prinsip-Prinsip Islam. Malang: Setara Press.

Wiwoho, J. (2014). Peran lembaga keuangan bank dan lembaga keuangan bukan bank dalam memberikan Distribusi keadilan bagi masyarakat. MasalahMasalah Hukum, 43(1), 87-97. 